\title{
BYSSINOSIS: THE ACUTE EFFECT ON VENTILATORY CAPACITY OF DUSTS IN COTTON GINNERIES, COTTON, SISAL, AND JUTE MILLS \\ BY
}

\author{
J. C. GILSON, ${ }^{*}$ H. STOTT, $†$ B. E. C. HOPWOOD, $\ddagger$ S. A. ROACH, \\ C. B. MCKERROW,* and R. S. F. SCHILLING
}

(RECEIVED FOR PUBLICATION JULY 14, 1961)

\begin{abstract}
Studies of ventilatory capacity change in small groups of employees during a shift in a cotton mill and in three cotton ginneries in Uganda, a sisal factory in Kenya, and a jute mill in England, have demonstrated that an effect is produced by the dust in the cotton mill and in a very dusty ginnery but not in two other less dusty ginneries. No significant effect was detected in the sisal factory or in the jute mill despite much higher dust concentrations than in the cotton mill.

The dust sampling instruments gave the weight in three sizes: Coarse $(>2 \mathrm{~mm}$.), medium ( $7 \mu$ to $2 \mathrm{~mm}$.), and fine $(<7 \mu)$. The samples were analysed for protein, mineral (ash), and cellulose (by difference). The fine and medium sisal and jute dusts contain less protein than cotton dusts. The physiological changes observed in the employees in the cotton mill indicate the need for general dust measurement and control, even when new carding machinery is installed in a new mill.
\end{abstract}

The ventilatory capacity of normal subjects and of those with byssinosis falls during the course of a day's exposure to the dust in cotton mill card-rooms (McKerrow, McDermott, Gilson, and Schilling, 1958; Bouhuys, Lindell, and Lundin, 1960). The agent producing this effect has not yet been isolated. Davenport and Paton (1962) have shown that cotton dust extracts contain a smooth muscle contractor substance which may be responsible. Antweiler (1960) believes that the agent is a histamine releaser, and Pernis, Vigliani, Cavagna, and Finulli (1961) have suggested that the effect may be due to bacterial endotoxins. Tuffnell (1960) suggests that the substance is in the bracts and pericarp of the cotton boll; this is supported by Nicholls (1962) who has confirmed the presence of a smooth muscle contractor substance in extracts of these parts of the plant and has shown that it caused contraction of isolated human bronchial muscle. Nicholls has also investigated extracts of dust from flax, sisal, and jute mills and found decreasing activity in this order.

Here we report complementary studies of the

Present addresses :

* Medical Research Council, Pneumoconiosis Research Unit, Llandough Hospital, Penarth, Glamorgan.

†Tuberculosis Chemotherapy Centre, Government Tuberculosis Institute, Chetput, Madras-31, India.

$\ddagger$ Ministry of Health, Entebbe, Uganda, East Africa.

\$The Department of Occupational Health, London School of Hygiene and Tropical Medicine, Keppel Street, London, W.C.1. effect of exposure to the dusts during a day on workers in a cotton textile mill and in cotton ginneries in Uganda, and also in a sisal factory in Kenya and in a jute mill in England.

Mair, Smith, Wilson, and Lockhart (1960) found no symptoms resembling those of byssinosis in jute workers in Scotland, and no change in ventilatory capacity during the day, but there were symptoms of byssinosis in flax workers, and those with these symptoms showed the characteristic change of ventilatory capacity during the day. Smiley (1961), in a delightful review of the history and present position in mills in Ulster, showed clearly that the symptoms of byssinosis were recognized there more than a hundred years ago in the flax industry, and are still encountered and may be associated with disability (Logan, 1959).

Byssinosis has not been reported in workers in cotton ginneries where the cotton seed is separated from the linters, so when an opportunity arose it seemed worth investigating whether the acute effect on ventilatory capacity also occurred in workers in these factories.

General Plan and Methods

The general plan was the same in all the investigations. Repeated measurements of ventilatory 
capacity of the workers (male) normally employed in these mills and factories were made during the course of a day when they were not exposed to dust, and a similar series of measurements was carried out on a day when they were doing their normal job. The men who volunteered were, in general, those working in the dustier processes.

The forced expiratory volume (F.E.V $\cdot_{0.75}$ ) was measured with a standardized spirometer and timer (McKerrow, McDermott, and Gilson, 1960) and is expressed as an indirect maximum breathing capacity (I.M.B.C.) by multiplying the volume by 40 . Special care was taken to avoid or allow for changes in ambient temperature which might have led to a bias in the readings during the course of a day. In the investigations in Uganda the peak expiratory flow (Wright and McKerrow, 1959) was also measured, and in Kenya the F.E.V. was measured in addition on a low inertia spirometer (Bernstein, D'Silva, and Mendel, 1952). Weight and sitting height were recorded, and age was estimated for the African workers from whom an accurate statement could not be obtained.

The airborne dust in the mill or factory was sampled over a whole shift in the area in which the workers were employed in order to provide a gravimetric measure of dust concentration, and to obtain material for compositional analysis.

The equipment described by Roach and Schilling (1960) was used. This gives three sized components for the dust: (i) "Coarse"-this is the long fibres together with some adherent smaller dust which is retained on the $2 \mathrm{~mm}$. gauze in front of the filter paper; this fraction (too large to enter even the upper part of the respiratory tract) is removed periodically to prevent blocking the sampler; (ii) "medium and fine" together is the dust which collects on the filter paper behind the gauze; (iii) the "fine" is the dust which collects on a filter paper in front of which is a horizontal elutriator designed to cut off $100 \%$ of particles $>7 \cdot 1 \mu$ equivalent diameter (Wright, 1954). The weight of "medium" dust is obtained by difference.

Aliquot samples of the dusts were analysed for organic nitrogenous matter, i.e. protein, by micro$\mathrm{Kjeldahl,} \mathrm{and} \mathrm{for} \mathrm{ash,} \mathrm{i.e.} \mathrm{mineral,} \mathrm{and} \mathrm{the} \mathrm{difference}$ reported as cellulose which is its principal constituent.

It is important to emphasize that the short period of these investigations seriously limited the comprehensiveness of the dust sampling, so that the results are indications of the dustiness and are not comparable in accuracy to the findings in Lancashire cotton mills reported by Roach and Schilling. Also in Africa there were various technical difficulties which prevented the collection of sufficient samples for detailed analysis of composition in three sized components in all cases. In view of the findings of McKerrow, Roach, Gilson, and Schilling (1962) it seems probable that the quantity of fine dust and particularly the mass concentration of its protein may best be related to the acute change of ventilatory capacity.

A. A Cotton Textile Mill in Uganda.-This is a large, recently opened, modern, well-lighted mill under a single roof (Fig. 1) spinning medium length staple (30/32 in.). The carding machines are at one end of the main factory which also houses the intermediate frames and spindles; only the blowroom is separate. The general current of air is from the spindles towards the cards, but there is no local dust extraction over the cards except during stripping and grinding. As the lay-out is on one floor there is probably more general dispersion of dust from the cards to other parts of the mill than is encountered in a typical multi-storey Lancashire mill.

Twelve African regular workers (four strippers and grinders, one blow-room worker, three drawers, and four spinners) volunteered for the tests. They had worked for between 44 and 15 months in the mill; their mean age was estimated at 23 years (range 19 to 36). The "out-of-dust" tests of ventilatory capacity were made at 4,7 , and 10 p.m. on a Sunday (their previous shift ended at 8 a.m. on the Saturday). The "in-dust" tests were made at 3.45, 8 , and 11.15 p.m. on the Monday, the first test being made before they had started work.

Physiological Results.-Table 1 shows that the mean I.M.B.C. of the workers did not fall significantly "out-of-dust", but "in-dust" there was an average fall of $7.51 . / \mathrm{min}$. which was highly significant. However, the difference in rate of change of I.M.B.C. on the two days could reflect chance variation $(0 \cdot 20>p>0 \cdot 10)$. The peak flow measurement fell from an average of $4811 . / \mathrm{min}$. to $4511 . / \mathrm{min}$. out of dust, and from $4441 . / \mathrm{min}$. to $4241 . / \mathrm{min}$. in dust, but neither of these changes is significant. This is not surprising because previous studies have shown that the peak flow is a less sensitive measure of change because it is more dependent than the F.E.V. on the effort and hence motivation of the subject. One man, aged about 22, had an I.M.B.C. of only 50 $1 . / \mathrm{min}$. which fell by nearly $50 \%$ while he was working in the dust. This man had worked for 15 months in the mill.

Dust Concentrations.-The dust samples were collected near the middle of the bank of carding machines. The total dust concentration was 453 $\mathrm{mg} . / 100 \mathrm{~m} .{ }^{3}$ (Table 2). This and the percentage of protein and mineral in the fine and medium dust are similar to the average of many samples for the cardrooms in the lower grade cotton mills in Lancashire 


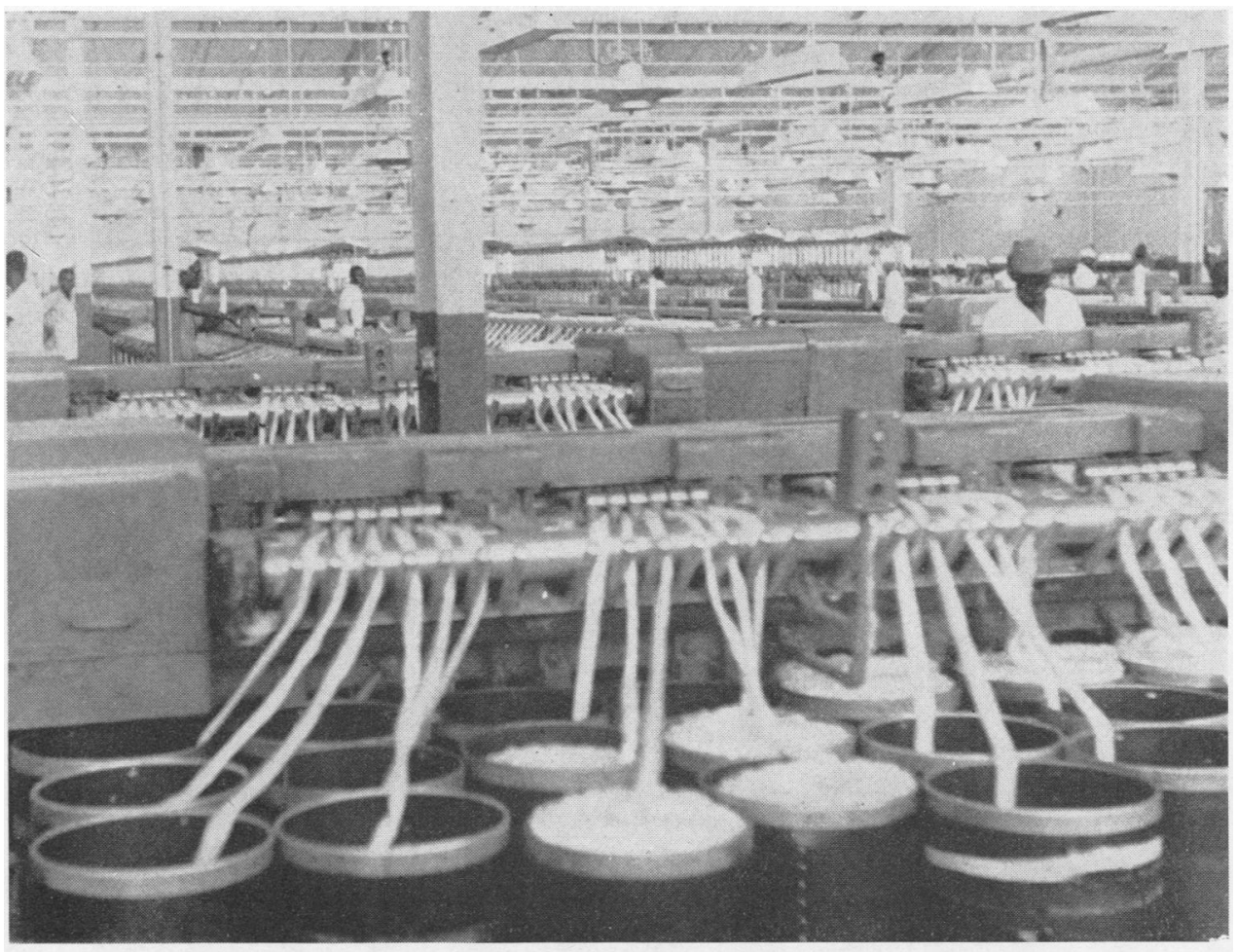

FIG. 1.-A modern textile mill in Uganda, showing the slivers.

TABLE 1

CHANGES OF INDIRECT MAXIMUM BREATHING CAPACITY DURING A SHIFT SPENT "IN" AND "OUT" OF DUST IN A COTTON MILL, THREE COTTON GINNERIES, AND A SISAL FACTORY IN EAST AFRICA

\begin{tabular}{|c|c|c|c|c|c|c|c|c|c|c|c|}
\hline & \multirow[b]{2}{*}{ Factory } & \multirow{2}{*}{$\begin{array}{l}\text { No. of } \\
\text { Subjects }\end{array}$} & \multirow{2}{*}{$\begin{array}{l}\text { Mean } \\
\text { Sitting } \\
\text { Height } \\
\text { (in.) }\end{array}$} & \multirow{2}{*}{$\begin{array}{c}\text { Mean } \\
\text { Weight } \\
\text { (lb.) }\end{array}$} & \multirow{2}{*}{$\begin{array}{l}\text { Estimated } \\
\text { Mean } \\
\text { Age }\end{array}$} & \multirow[b]{2}{*}{ Time } & \multicolumn{2}{|c|}{ "Out of Dust" } & \multicolumn{2}{|c|}{ "In Dust" } & \multirow{2}{*}{$\begin{array}{l}\text { Significance of } \\
\text { Difference } \\
\text { of Slopes }\end{array}$} \\
\hline & & & & & & & I.M.B.C. & $\begin{array}{c}\text { Slope } \\
(1 . / \mathrm{min} . / \mathrm{hr} .)\end{array}$ & $\begin{array}{l}\text { I.M.B.C. } \\
\text { (1./min. })\end{array}$ & $\begin{array}{c}\text { Slope } \\
\text { (1. } / \mathrm{min} . / \mathrm{hr} .)\end{array}$ & \\
\hline A & $\begin{array}{l}\text { Cotton } \\
\text { textil: } \\
\text { mili }\end{array}$ & 12 & $33 \cdot 5$ & 130 & 23 & $\begin{array}{l}\text { a } \\
\text { b } \\
c\end{array}$ & $\begin{array}{l}112.9 \\
114.0 \\
110.0\end{array}$ & $\begin{array}{l}-0.37 \\
\text { N.S. }\end{array}$ & $\begin{array}{l}114 \cdot 7 \\
108 \cdot 3 \\
107 \cdot 2\end{array}$ & $\begin{array}{c}-0.94 \\
p=0.001\end{array}$ & $\begin{aligned} & \text { N.S. } \\
0.20>p & >0.10\end{aligned}$ \\
\hline \multirow{3}{*}{ B } & $\begin{array}{l}\text { Ginnery } \mathrm{K} \\
\text { "Safi" }\end{array}$ & 9 & $33 \cdot 0$ & 130 & 25 & $\begin{array}{l}\mathrm{a} \\
\mathrm{b} \\
\mathrm{c}\end{array}$ & $\begin{array}{l}11 \overline{6 \cdot 0}^{*} \\
113 \cdot 7\end{array}$ & N.S. & $\begin{array}{l}110 \cdot 6 \\
107.6 \\
107.6\end{array}$ & $\begin{array}{l}-0.38 \\
\text { N.S. }\end{array}$ & N.S. \\
\hline & \multirow{2}{*}{$\begin{array}{l}\text { Ginnery V } \\
\text { "Safi" } \\
\text { Ginnery } \\
\text { "Fifi" }\end{array}$} & 8 & $34 \cdot 3$ & 142 & 29 & $\begin{array}{l}\mathrm{a} \\
\mathrm{b} \\
\mathrm{c}\end{array}$ & $\begin{array}{l}133 \cdot 2 \\
127 \cdot 5 \\
129 \cdot 3\end{array}$ & $\begin{array}{l}-0.27 \\
\text { N.S. }\end{array}$ & $\begin{array}{l}122 \cdot 5 \\
120 \cdot 6 \\
121 \cdot 2\end{array}$ & $\begin{array}{l}-0.16 \\
\text { N.S. }\end{array}$ & N.S. \\
\hline & & 11 & $33 \cdot 6$ & $133 \cdot 6$ & 25 & $\begin{array}{l}a \\
b \\
c\end{array}$ & $\begin{array}{l}120.4 \\
118.8 \\
118.8\end{array}$ & $\begin{array}{l}-0.19 \\
\text { N.S. }\end{array}$ & $\begin{array}{r}104 \cdot 6 \\
98 \cdot 8 \\
95 \cdot 3\end{array}$ & $\begin{array}{c}-1.17 \\
p<0.001\end{array}$ & $0.01>p$. \\
\hline \multirow{2}{*}{ C } & $\begin{array}{c}\text { Sisal } \\
\text { factory A }\end{array}$ & 10 & $33 \cdot 1$ & 120 & 20 & $\begin{array}{l}\mathrm{a} \\
\mathrm{b} \\
\mathrm{c}\end{array}$ & $\begin{array}{l}116.7 \\
118.9 \\
121 \cdot 0\end{array}$ & $\begin{array}{c}+0.54 \\
0.05>p>0.01\end{array}$ & $\begin{array}{l}116.6 \\
115.5 \\
112.7\end{array}$ & $\begin{array}{l}-0.49 \\
\text { N.S. }\end{array}$ & $0.05>p>0.01$ \\
\hline & $\underset{\text { factory B }}{\text { Bisal }}$ & 10 & $33 \cdot 3$ & 124 & 29 & $\begin{array}{l}\mathrm{a} \\
\mathrm{b} \\
\mathrm{c}\end{array}$ & $\begin{array}{l}121.9 \\
125.0 \\
121.0\end{array}$ & $\begin{array}{l}<0.1 \\
\text { N.S. }\end{array}$ & $\begin{array}{l}119.1 \\
118.9 \\
118.6\end{array}$ & $\begin{array}{l}<0.1 \\
\text { N.S. }\end{array}$ & N.S. \\
\hline
\end{tabular}

$a=$ before shift $; b=$ middle of shift $; c=$ near end of shift. ${ }^{*}$ Technical failure. 
TABLE 2

DUST CONCENTRATIONS (mg./100 m. ${ }^{3}$ IN EAST AFRICAN COTTON AND SISAL MILLS AND COTTON GINNERIES COMPARED WITH LANCASHIRE COTTON MILLS

\begin{tabular}{|c|c|c|c|c|c|}
\hline Mill & Coarse* & Medium* & Fine* & Total (all sizes) & Constituents \\
\hline \multirow[t]{2}{*}{$\begin{array}{l}\text { Lancashire mills (coarse) } \\
\text { cards } \dagger\end{array}$} & $\begin{array}{r}(8) \\
(85) \\
(7)\end{array}$ & $\begin{array}{l}(21) \\
(51) \\
(28)\end{array}$ & $\begin{array}{l}(21) \\
(45) \\
(34)\end{array}$ & & $\begin{array}{l}\text { Protein } \\
\text { Cellulose } \\
\text { Mineral }\end{array}$ \\
\hline & (63) & (30) & (7) & $440(100)$ & Total \\
\hline \multirow[t]{2}{*}{$\begin{array}{l}\text { Cotton textile mill in Uganda, } \\
\text { cards }\end{array}$} & $\begin{array}{r}36(10) \\
270(80) \\
30(10)\end{array}$ & $\begin{array}{l}14(23) \\
22(37) \\
24(40)\end{array}$ & $\begin{array}{l}15(26) \\
26(40) \\
16(34)\end{array}$ & $\begin{array}{r}65 \\
318 \\
70\end{array}$ & $\begin{array}{l}\text { Protein } \\
\text { Cellulose } \\
\text { Mineral }\end{array}$ \\
\hline & $(74)$ & (13) & $57 \quad$ (13) & $453(100)$ & Total \\
\hline \multirow[t]{2}{*}{$\begin{array}{l}\text { Ginnery } \mathrm{K} \text { near openers } \\
\text { "Saf"" }\end{array}$} & $\left.\begin{array}{r}5(11) \\
42(89)\end{array}\right\}$ & \multicolumn{2}{|c|}{$\begin{array}{r}81(14) \\
216(38) \\
270(48)\end{array}$} & $\begin{array}{c}86 \\
247 \ddagger\end{array}$ & $\begin{array}{l}\text { Protein } \\
\text { Cellulose } \\
\text { Mineral }\end{array}$ \\
\hline & 47 & 567 & (93) & $614(100)$ & Total \\
\hline \multirow[t]{2}{*}{$\begin{array}{l}\text { Ginnery, V near openers } \\
\text { "Safi" }\end{array}$} & $\begin{array}{r}24(14) \\
116(65) \\
38(21)\end{array}$ & \multicolumn{2}{|c|}{$\begin{array}{r}66(19) \\
102(29) \\
178(52)\end{array}$} & $\begin{array}{r}90 \\
218 \\
216\end{array}$ & $\begin{array}{l}\text { Protein } \\
\text { Cellulose } \\
\text { Mineral }\end{array}$ \\
\hline & (34) & 346 & (66) & $524(100)$ & Total \\
\hline \multirow[t]{2}{*}{$\begin{array}{l}\text { Ginnery near openers } \\
\text { "Fifi" }\end{array}$} & $\begin{array}{r}88(16) \\
330(58) \\
150(26)\end{array}$ & $\begin{array}{r}535(13) \\
1,111(27) \\
2,434(60)\end{array}$ & $\begin{array}{l}191(17) \\
317(29) \\
600(54)\end{array}$ & $\begin{array}{r}814 \\
1,758 \\
3,184\end{array}$ & $\begin{array}{l}\text { Protein } \\
\text { Cellulose } \\
\text { Mineral }\end{array}$ \\
\hline & $(10)$ & 4,080 & 1,108 & $5,756(100)$ & Total \\
\hline \multirow[t]{2}{*}{ Sisal factory, Kenya } & $\frac{\text { Nil }}{-}$ & $\begin{array}{r}22(5) \\
274(61) \\
152(34)\end{array}$ & $\begin{array}{c}14(9) \\
108(69) \\
35(22)\end{array}$ & $\begin{array}{r}36 \\
382 \\
187\end{array}$ & $\begin{array}{l}\text { Protein } \\
\text { Cellulose } \\
\text { Mineral }\end{array}$ \\
\hline & - & $(74)$ & $(26)$ & $605(100)$ & Total \\
\hline
\end{tabular}

*For definitions, see text. †From Roach and Schilling (1960). The figures in brackets are percentages.

reported by Roach and Schilling (1960), but the ratio of "coarse" to "medium and fine" dust together was higher than is typical in the lower grade cotton mills of Lancashire so that the mass of respirable dust (medium and fine) in the Uganda mill was lower than in the coarse mills in Lancashire and similar to that of the less dusty higher grade mills surveyed by Roach and Schilling.

We believe that this investigation shows that the same effects on ventilatory capacity reported in workers in cotton mills in Europe (McKerrow et al., 1958) and America (McKerrow and Schilling, 1961) also occur in the Africans working in Uganda.

B. Three Cotton Ginneries in Uganda.-In Uganda the cotton is picked by hand and then sorted into two grades. The cleaner grade is known as "safi" and commands a higher price; the remainder, "fiff", is much dirtier, the dirt being partly soil and partly discoloration by moulds. In each ginnery it is usual to gin the "saf" first, and end up with the relatively small amount of "fifi".

Most of the ginneries in Uganda have recently been rebuilt and the new buildings are designed to make the maximum use of thermal currents caused by the sun shining on the roof, to maintain good ventilation. Casual labour is employed which changes from one season (about four months) to the next, so that there are very few Africans with several years' service. Compared with the textile mill the labour is less disciplined and an appreciable part of the working time is spent outside the shed sitting in the shade (Fig. 2). For these reasons and technical ones concerned with the timing mechanism of the spirometer and the dust samplers, the studies in the two ginneries processing "saf" did not produce results on which we can rely as certainly as those in the textile factory. The results in the "fifi" ginnery were technically more satisfactory.

The process of ginning is essentially one of combing the seed out of the linters and it may be important in considering the results in the ginneries to realize that not much separation of the smaller pieces of pericarp and bracts from the linters occurs. It is the separation of these two which occurs principally in the blow-rooms and card-rooms of the spinning mills.

Ginning "Saf".--In one ginnery, 12 and in the other, 11 subjects were chosen from among those who were working in the dustier parts of the sheds. These men were studied "out-of-dust" on one day 


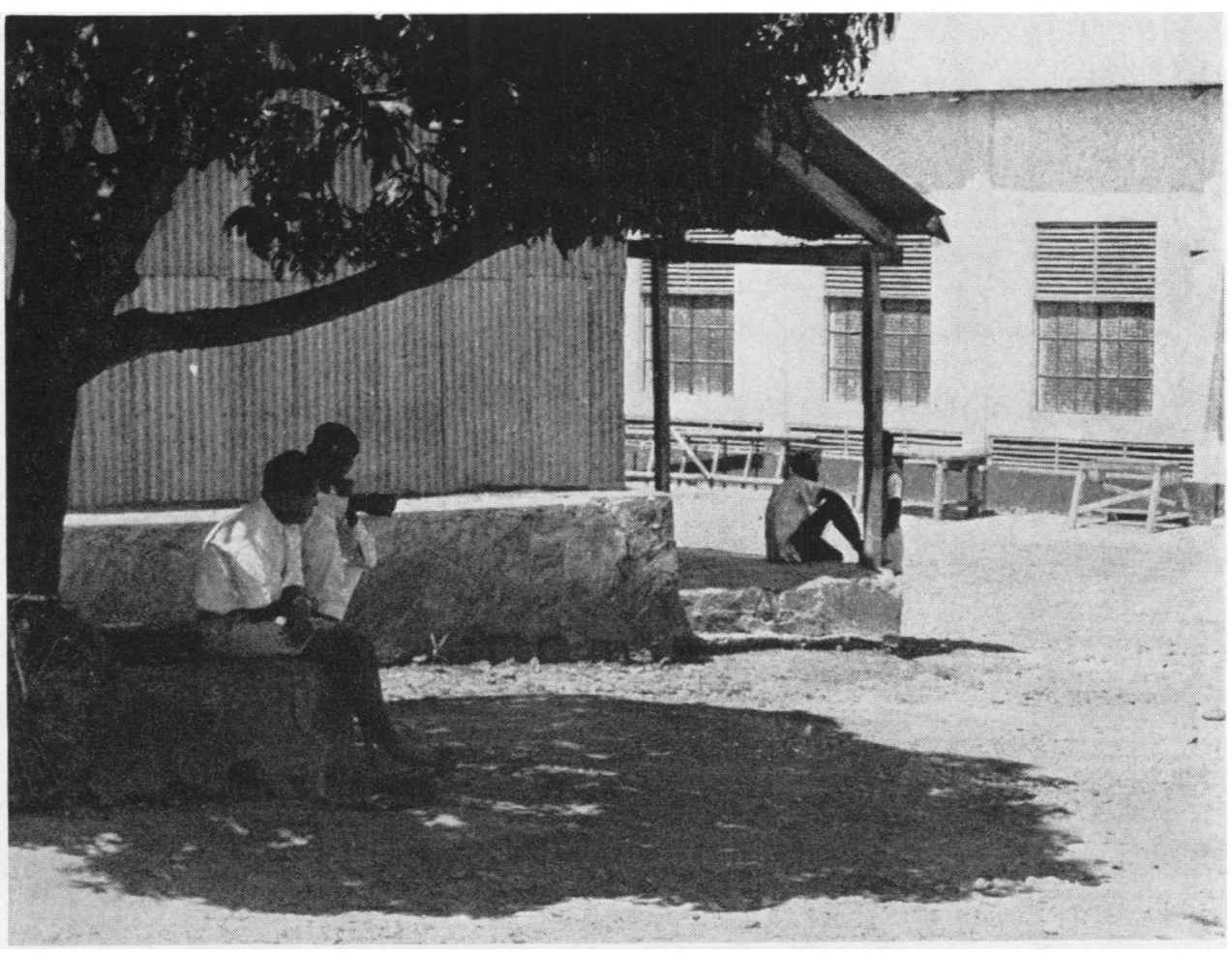

FIG. 2.-An alternative way of avoiding ginnery dust.

and again "in-dust" on the next. In both ginneries three of the men failed to complete the six tests of ventilatory capacity satisfactorily; these men have been omitted. At the second ginnery, competition to achieve the best blow was so intense that it led to a good-humoured fight on the second day between some of the workers, so that we cannot really claim that our results are uninfluenced by emotional factors leading, perhaps, to liberation of endogenous adrenalin!

Physiological Results.-Table 1 shows that in neither ginnery processing "safi" was there a significant change of I.M.B.C. during the day either "in" or "out" of dust. The lower absolute value of I.M.B.C. on the "in-dust" day as compared with the "out-of-dust" day in ginnery $V$ is technical, but does not affect the validity of any change during this day.

Dust Concentrations.--Table 2 shows that although the total dust concentration in these two ginneries was not much higher than in the textile mill, yet the concentration of medium and fine together was between three and five times higher. Technical failures prevented collection of the fine dust separately. The percentage of protein in the medium and fine together was similar to that in the cotton mill.

The absence of a physiological effect of this high dust concentration is surprising. An inspection of the individual results showed that no man had a fall of I.M.B.C. "in-dust" as great as $5 \%$. A false negative result is not very probable, because failure to co-operate fully is likely to produce a low reading of ventilatory capacity, and those who completed the series of tests seemed to be doing the test well and there was no striking random scatter of results.

It is possible that the amount of the physiologically active agent is low in ginnery dust, or that the men we studied were not really exposed to the dust concentrations we measured. The latter explanation is certainly partly true because none of the workers spent all the time in the shed.

Ginning "Fifi".- The buildings had not been completely modernized and the dust conditions were visually much worse than in the "safi" ginneries; many men wore a piece of cloth over their face (Fig. 3). Eleven out of the 15 volunteers were tested satisfactorily "out-of-dust" on a Sunday and again 


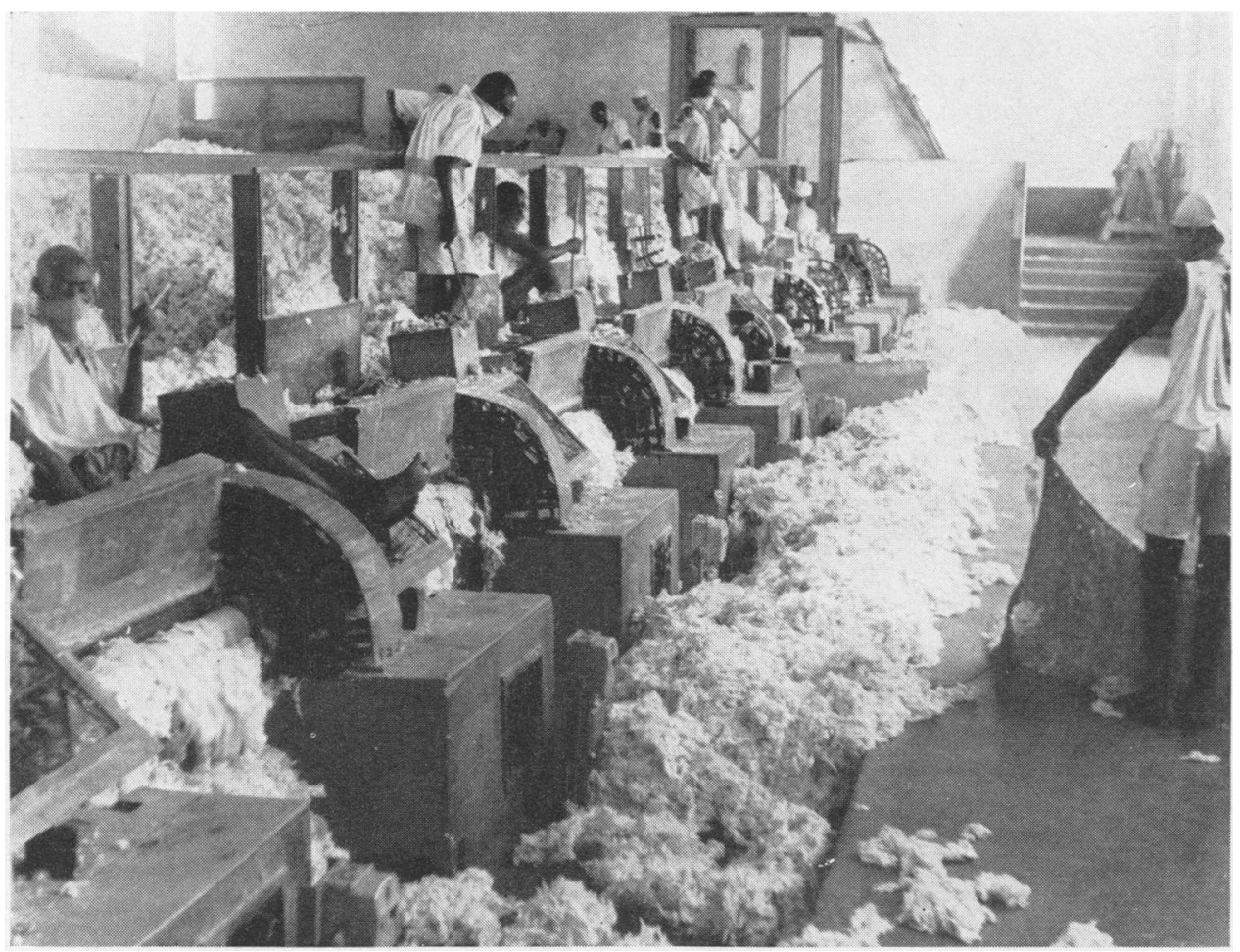

FIG. 3.-Ginning "fifi". Many workers wear a handkerchief across the mouth and nose.

"in-dust" on a Monday. The remaining four missed one or more tests and have been omitted from the analysis.

Physiological Results.-Table 1 shows there was no significant change of I.M.B.C. during the Sunday, but when working "in-dust" on the Monday there was a highly significant fall of ventilatory capacity, and also the rate of fall of I.M.B.C. during the day "in-dust" was significantly greater than "out-ofdust". The absolute values of the I.M.B.C. were much lower on the "in-dust" day (Table 1); this is due to having to replace the relay on the spirometer on that day before the start of the tests, but it does not affect the validity of the change observed during the day.

Dust Concentrations.-Table 2 shows that the visual impressions were fully confirmed. The total dust concentration was about $\mathbf{1 0}$ times as high as in the two factories ginning "safi" and the fine dust was 20 times that in the textile mill. Again the proportion of medium and fine to total dust was high. The mineral content was also relatively higher than in the textile mill.

We conclude that when dust conditions in ginneries are severe, a fall of ventilatory capacity also occurs. However, taking into account the relative dustiness, the effect is much less marked than in cotton mills. The average fall of I.M.B.C. of about $9 \%$ in this "fifi" ginnery is less than would be expected in a card-room with one-tenth of the dust concentration. The biggest reduction of ventilatory capacity recorded in one individual was $17 \mathrm{l} . / \mathrm{min}$. The average peak flow increased on the "out-of dust" day from 481 to $5021 . / \mathrm{min}$., but "in-dust" fell from 495 to $470 \mathrm{l} . / \mathrm{min}$.; thus, although this measurement again indicated the effect of the dust, the percentage change was only about half that of the F.E.V. The cloth over the face may have provided some protection and so reduced the change of ventilatory capacity.

C. A Sisal Factory in Kenya.--Sisal is made from the thick fleshy leaves of the Agave. The leaves are decorticated by a wet retting process and then brushed clean. This process is said to be very dusty but was not investigated in this study. The resultant lo.ng fibres are baled and sent to the factories for spinning and weaving. The spinning process is similar to that used in cotton. The raw fibre arrives 
at the factory baled and is first fed through "breakers"; these correspond roughly to the carding machines of the cotton mills and are the principal dust producers in the sisal spinning and weaving process.

The factory has been described by Stott (1958). On account of the high degree of co-operation expected from the African workers, a more elaborate plan was used than in the case of the studies in Uganda. Two groups of 10 workers were chosen. Group A were men who had recently come to the factory and were working on buildings outside and had not previously worked in the factory. Group B were the men normally working in the dustier parts of the factory. Men in Group A were tested first on a day when they were working outside and again on another day when they were working inside the factory on the dustier processes as substitutes for the men in Group B. Group B were tested both during a normal day's work and also on a day when they were at the factory but were not inside the mill. In addition, both groups did a series of tests on a day before the main experiment in order to learn how to do the tests, so that errors arising in the main experiment through a learning effect could be reduced as far as possible.

Physiological Results.-Table 1 shows that in Group A, while they were "out-of-dust", there was a rise of I.M.B.C. during the course of the day which was significant, while during the day on which they were "in-dust" there was a fall of I.M.B.C. which might have been due to chance. However, due to the reverse trends on the two days the difference in slope of the rate of change of I.M.B.C. during the day was statistically significant. In Group B, "out-of-dust", there was no appreciable change during the day, but "in-dust" there was a small reduction which was not significant, and there was no significant difference between the slopes of the rate of change in and out of dust. We must conclude that there was no clear evidence of an acute effect of the dust in these two groups. The tests made with the low inertia recording spirometer led to the same conclusion.

Dust Concentrations. - Table 2 shows that the total dust concentration near the "breakers" was similar to the cotton textile mill, but there was no coarse dust so that the concentration of medium dust was about seven times as great, and fine dust three times as great as in the cotton mill. Also the concentration of medium and fine combined is more than three times that in the average card-room of coarse mills in Lancashire, while the fine dust concentration is five times as great. Thus, as this sisal factory investigation was technically satisfactory both in dust sampling and in the physiological studies, we conclude that sisal dust in this part of the process is virtually free of the active component present in cotton dust. The percentage of protein in the fine and medium dust is much lower-about one-third to one-quarter-than that in cotton dust of the same size, but the total protein in the medium and fine dust is similar in the textile and sisal mills. During a small part of the experiment the ventilating system of the mill was not running.

D. A Jute Mill in England.-Jute comes mostly from Pakistan and India and is the fibre lying between the bark and the woody core of two species of Tiliaceae: Corchorous Capsularis and Olitorius. After harvesting, the reeds are steeped in stagnant water for some days or weeks. During this retting process, which is similar to that used for sisal, the fleshy parts of the plant decompose leaving the fibres intact; they are then cleaned, dried, graded, and baled. The bales arrive at the spinning mills where the process used is similar to that employed in sisal. The processes of opening the bales, mixing the appropriate grades of fibre, and feeding them through the spreader and on the breaker card to form the sliver, produce most of the dust.

Our investigations were made in two stages in a jute mill in England. In the first stage two of us (R.S.F.S. and S.A.R.) interviewed 21 of the 30 employees working in the preparing and spinning sections of the mill. At this interview on a Friday a preliminary measurement of I.M.B.C. was recorded and an inquiry about symptoms of chest tightness made. In the second stage, on the following Monday, one of us (C.B.McK.) made two I.M.B.C. measurements-one at the start of the shift (between 7.45 and 8.45 a.m.) and one at the end (between 3.45 and 5.15 p.m.). In this second stage, 18 of the 21 subjects seen on the Friday were present, together with two other people, making a total of 20 subjects. In view of our past experience, we considered it unnecessary to make a separate study of these people on a day out of dust.

Dust measurements in the area of the spreader, the cards, and the spinning frames were made during the second stage. It happened that on this day, due to a temporary failure of part of the ventilating system, the dustiness was considerably higher than usual, as indicated by a comparison with similar dust measurements made later in the same week when the ventilating equipment had been repaired (see Table 4).

Physiological Results.

StaGe I.-None of the 21 employees interviewed gave the characteristic history of tightness of the 
chest on Mondays, reported in cotton mills; six reported occasional tightness unrelated to work, but occurring with changes in the weather. These men also had symptoms of bronchitis, but were working in the dustier parts of the process.

StaGe II.-Table 3 shows I.M.B.C. before and after the shift on the Monday with the employees divided into two groups: those exposed to the less dusty (Group A) and dustier (Group B) jobs. In those working in the less dusty jobs there was an average increase of I.M.B.C. from 114.7 to 116.3 1./min. Those in the dustier jobs showed a fall from 113.9 to $113.51 . / \mathrm{min}$. Neither of these changes is statistically significant. There is also no clear relationship between the symptoms of tightness and change of I.M.B.C. Those in Group A had worked an average of 10 years in the factory, and those in Group B 14 years. The close agreement of average I.M.B.C. recorded in Stage I and Stage II is evidence of how little this test is dependent on the observer when care is taken with the technique and standardization of the spirometer. We conclude that in this mill and in the concentrations of dust to which the employees were exposed, there is no important effect of the dust on the ventilatory capacity during a day.

Dust Concentrations.-Table 4 shows the dust concentrations at the spreaders, the cards, and the spinning frames during Stage II and two days later. It shows that on the day of the investigation the dust levels were unusually high. There is also relatively more fine dust near the spreader and cards than in the spinning section of the mill. The concentration of fine dust is greater than that in the sisal factory in Kenya, and about three times as great as in the cotton textile mill in Uganda where a significant fall of I.M.B.C. was observed. The percentage of protein in the fine and medium jute dust is about $10 \%$, and about the same as that in the sisal dust, and about half the typical value for cotton dust. The explanation is presumably the same as in the case of sisal, i.e. a wet retting process removing the soluble materials.

\section{Discussion}

The average I.M.B.C. of the African workers is at least $201 . / \mathrm{min}$. lower than would be expected for Europeans of the same age. The difference can be explained partly by their small size (about 2 in. shorter sitting height), but this would only account for about $12 \mathrm{l} . / \mathrm{min}$.; the remainder is at present unexplained.

The acute effects on lung function of the dusts in cotton mills in Europe might be caused by bacterial or mould action on the cotton between the time it is baled in the producer countries and opened months or years later in the mills. The low humidity in the bales (about $8 \%$ ) and the absence of any increase in smooth muscle contractor activity of the cotton dust even when kept at relatively high humidity and temperature (Nicholls, 1962) make this hypothesis

TABLE 3

CHANGE OF INDIRECT MAXIMUM BREATHING CAPACITY DURING A SHIFT IN A JUTE MILL

\begin{tabular}{|c|c|c|c|c|c|c|c|c|}
\hline \multirow{3}{*}{ Subject } & \multirow{3}{*}{ Age } & \multirow{3}{*}{ Sex } & \multirow{3}{*}{ Occupation } & \multirow{3}{*}{ Tightness } & \multicolumn{3}{|c|}{ I.M.B.C. } & \multirow{3}{*}{ Difference } \\
\hline & & & & & \multirow{2}{*}{ Friday Stage I } & \multicolumn{2}{|c|}{ Monday Stage II } & \\
\hline & & & & & & Before & After & \\
\hline $\begin{array}{l}\text { C.B. } \\
\text { G.H. } \\
\text { M.M. } \\
\text { D.B. } \\
\text { H.J. } \\
\text { M.P. } \\
\text { F.T. } \\
\text { T T. } \\
\text { R.W. }\end{array}$ & $\begin{array}{l}28 \\
49 \\
25 \\
38 \\
17 \\
61 \\
33 \\
17 \\
28\end{array}$ & $\begin{array}{l}\mathbf{F} \\
\mathbf{F} \\
\mathbf{F} \\
\mathbf{M} \\
\mathbf{M} \\
\mathbf{M} \\
\mathbf{M} \\
\mathbf{M} \\
\mathbf{M}\end{array}$ & \begin{tabular}{l} 
Drawer \\
Drawer \\
Drawer \\
Doffer \\
\multicolumn{1}{c}{-} \\
Spinner \\
Doffer \\
Drawer
\end{tabular} & $\begin{array}{l}-\overline{0} \\
0 \\
0 \\
0 \\
0 \\
0 \\
0\end{array}$ & $\begin{array}{r}\overline{47} \\
119 \\
105 \\
173 \\
1 \overline{35} \\
148 \\
127\end{array}$ & $\begin{array}{r}78 \cdot 3 \\
53 \cdot 3 \\
123 \cdot 5 \\
104 \cdot 3 \\
162 \cdot 0 \\
95 \cdot 7 \\
130 \cdot 7 \\
149 \cdot 3 \\
135 \cdot 0 \\
\end{array}$ & $\begin{array}{r}76.7 \\
61.7 \\
121.0 \\
111.3 \\
171.7 \\
93.7 \\
135.7 \\
148.0 \\
127.0\end{array}$ & $\begin{array}{l}-1.6 \\
+8.4 \\
-2.5 \\
+7.0 \\
+9.7 \\
-2.0 \\
+5.0 \\
-1.3 \\
-8.0\end{array}$ \\
\hline Group A & & & & Mean & $122 \cdot 0$ & $114 \cdot 7^{*}$ & $116 \cdot 3$ & +1.6 \\
\hline $\begin{array}{l}\text { D.A. } \\
\text { G.B. } \\
\text { N.I. } \\
\text { J.K. } \\
\text { C.L. } \\
\text { S.N. } \\
\text { H.Q. . } \\
\text { J.T. } \\
\text { M.T. } \\
\text { R.T. } \\
\text { H.W. }\end{array}$ & $\begin{array}{l}41 \\
26 \\
30 \\
18 \\
30 \\
35 \\
46 \\
28 \\
19 \\
49 \\
48 \\
\end{array}$ & $\begin{array}{l}\mathbf{M} \\
\mathbf{M} \\
\mathbf{M} \\
\mathbf{M} \\
\mathbf{M} \\
\mathbf{M} \\
\mathbf{M} \\
\mathbf{M} \\
\mathbf{M} \\
\mathbf{M} \\
\mathbf{M} \\
\end{array}$ & $\begin{array}{l}\text { Waste carder } \\
\text { Carder } \\
\text { Splitter } \\
\text { Spreader } \\
\text { Preparing } \\
\text { Splitter } \\
\text { Opener } \\
\text { Carder } \\
\text { Spreader } \\
\text { Waste carder } \\
\text { Opener } \\
\end{array}$ & $\begin{array}{l}+ \\
0 \\
0 \\
0 \\
0 \\
+ \\
+ \\
0 \\
0 \\
+ \\
+\end{array}$ & $\begin{array}{r}67 \\
117 \\
113 \\
131 \\
143 \\
131 \\
44 \\
148 \\
158 \\
108 \\
101\end{array}$ & $\begin{array}{r}65 \cdot 7 \\
95 \cdot 7 \\
129 \cdot 3 \\
128.0 \\
141.0 \\
134.3 \\
51.0 \\
146.0 \\
158 \cdot 3 \\
103.7 \\
100 \cdot 3 \\
\end{array}$ & $\begin{array}{r}68 \cdot 0 \\
112.3 \\
127.7 \\
124 \cdot 3 \\
139.7 \\
135.7 \\
40.0 \\
144 \cdot 3 \\
150 \cdot 7 \\
107.3 \\
98 \cdot 3 \\
\end{array}$ & $\begin{array}{r}+2.5 \\
+16.6 \\
-1.6 \\
-3.7 \\
-1.3 \\
+1.4 \\
-11.0 \\
-1.7 \\
-7.6 \\
+3.6 \\
-4.0 \\
\end{array}$ \\
\hline Group B & & & & Mean & $114 \cdot 6$ & 113.9 & $113 \cdot 5$ & -0.4 \\
\hline
\end{tabular}

* Mean of the seven individuals who were also tested on Friday was $122.61 . / \mathrm{min}$. 
TABLE 4

DUST CONCENTRATIONS (mg./100m. ${ }^{3}$ ) IN JUTE MILL

\begin{tabular}{|c|c|c|c|c|c|c|}
\hline & Department & Coarse* & Medium* & Fine* & Total (all sizes) & Constituents \\
\hline \multirow[t]{6}{*}{$\begin{array}{l}\text { During stage II } \\
\text { (mean of two } 4 \cdot 5 \text {-hour } \\
\text { samples) }\end{array}$} & \multirow[t]{2}{*}{ Spreader } & \multirow[t]{2}{*}{-} & $\begin{array}{r}46(7) \\
214(34) \\
370(59)\end{array}$ & $\begin{array}{r}33(12) \\
125(46) \\
112(42)\end{array}$ & & $\begin{array}{l}\text { Protein } \\
\text { Cellulose } \\
\text { Mineral }\end{array}$ \\
\hline & & & 630 & 270 & $<900(100)$ & Total \\
\hline & \multirow[t]{2}{*}{ Cards } & & $\begin{array}{r}17(10) \\
43(25) \\
110(65)\end{array}$ & $\begin{array}{l}21(12) \\
96(57) \\
53(31)\end{array}$ & & $\begin{array}{l}\text { Protein } \\
\text { Cellulose } \\
\text { Mineral }\end{array}$ \\
\hline & & $89(20)$ & 170 & (40) & $429(100)$ & Total \\
\hline & \multirow[t]{2}{*}{ Spinning } & & $\begin{array}{l}8(7) \\
87(72) \\
25(21)\end{array}$ & $\begin{array}{r}<4(<27) \\
11(>73)\end{array}$ & & $\begin{array}{l}\text { Protein } \\
\text { Cellulose } \\
\text { Mineral }\end{array}$ \\
\hline & & $539(80)$ & 120 & (2) & $674(100)$ & Total \\
\hline \multirow[t]{6}{*}{$\begin{array}{l}\text { During two days after } \\
\text { stage II } \\
\text { (one !8-hour sample) }\end{array}$} & \multirow[t]{2}{*}{ Spreader } & 25 & $\begin{array}{r}2(10) \\
10(50) \\
9(40)\end{array}$ & $\begin{array}{r}3(14) \\
8(38) \\
10(48)\end{array}$ & & $\begin{array}{l}\text { Protein } \\
\text { Cellulose } \\
\text { Mineral }\end{array}$ \\
\hline & & $314(88)$ & (6) & (6) & $356(100)$ & Total \\
\hline & \multirow[t]{2}{*}{ Cards } & 56 & $\begin{array}{l}14(10) \\
73(53) \\
50(37)\end{array}$ & $\begin{array}{l}5(19) \\
11(42) \\
10(39)\end{array}$ & & $\begin{array}{l}\text { Protein } \\
\text { Cellulose } \\
\text { Mineral }\end{array}$ \\
\hline & & $291(64)$ & 137 & (16) & $454(100)$ & Total \\
\hline & \multirow[t]{2}{*}{ Spinning } & 8 & $\begin{array}{r}6(12) \\
29(56) \\
17(32)\end{array}$ & $\begin{array}{r}<1(17) \\
2(33) \\
3(50)\end{array}$ & & $\begin{array}{l}\text { Protein } \\
\text { Cellulose } \\
\text { Mineral }\end{array}$ \\
\hline & & $213(79)$ & (19) & (2) & $271(100)$ & Total \\
\hline
\end{tabular}

*For definitions, see text.

The figures in brackets are percentages.

improbable. In Uganda the cotton is spun shortly after picking, and now that we have shown that the cotton dust there produces acute effects in the African employees similar to those seen in the workers in Lancashire, this decay hypothesis is even more improbable.

We think the findings in the Uganda textile mill show the real need to install effective dust control in new cotton mills wherever they are built, because it seems highly probable that byssinosis will appear wherever the dust levels persistently exceed the provisional figures suggested by Roach and Schilling (1960) and where the labour stays long enough to acquire the disease. In the developing countries there is a natural trend to collect a skilled labour force with a low turnover, and this will increase the probability of the disease appearing. We were unsuccessful in an effort to investigate further the cause of the very low I.M.B.C. of the young man of 22 working in the textile mill. It is possible that he is an example of a high individual susceptibility to the dust. M. McDermott (1958, personal communication) has observed marked differences in susceptibility in normal subjects when studying the effect of mill dust on the lung airways resistance.

It might be argued that the demonstration of an effect of the dust during a day does not prove that byssinosis, a disease which usually takes years to develop, will result from prolonged exposure to such conditions. Evidence on this is still far from complete. It is not known whether those who show the greatest change of ventilatory capacity during a day are also those who eventually develop symptoms of the disease and disability with permanent reduction of ventilatory capacity (Schilling, 1959). However, the observation that a fall of ventilatory capacity during a shift only occurs in those working in parts of the cotton and flax mills where there is a relatively high prevalence of byssinosis, and does not occur in sisal and jute mills where byssinosis is rare, even though the dust concentrations are high, makes it probable that a change of ventilatory capacity during a day is a useful index of the byssinosis hazard of a natural fibre dust.

From a single sampling instrument on one day it is, of course, not possible to get a precise measure of the dustiness in the textile mill, but it may be advisable to investigate the dust conditions further as our figure for total dust is four times the provisional safe figure suggested by Roach and Schilling. The proportion of medium and fine to total dust in the Uganda textile factory is rather lower than that reported for Lancashire mills.

The demonstration of an acute effect of the cotton 
dust on the African worker adds to the evidence that chronic bronchitis is not closely linked with the condition of byssinosis in its early stages, because chronic bronchitis is rare among Africans (Paul, 1961). But it is, of course, probable that bronchitis does contribute to the disability caused by the disease in its later stages and especially in those highly industrialized countries where bronchitis is common.

The language difficulty prevented our making any useful inquiries about symptoms in Uganda, but many Africans wear a scarf over the face in the dustier parts of the ginneries, and when "fifi" is ginned, it is the custom to supply ginger to the employees to relieve the upper respiratory discomfort. In Kenya direct questioning of the African and European employees did not reveal any symptoms suggestive of byssinosis in the sisal factory.

We think it would be unwise to conclude from our studies that ginning "safi" is without any acute effect. There are many reasons why we may have failed to detect it. Not many men work in the dustiest parts of the factory and there may be considerable differences in the dust in different parts on account of the good thermal ventilation. Many men spend much of the time outside the factory. However, because the work is casual and seasonal, and "fifi" is only ginned for a very short period each year, and because a majority of the ginneries have been rebuilt and are now well ventilated it seems improbable that byssinosis is occurring at present in the ginneries in Uganda. However, it would be interesting to collect airborne ginnery dust for bioassay to see whether it does contain less pharmacological activity, weight for weight, than dust from the cotton mill.

The absence of any significant effect of the sisal dust is reassuring, especially as the concentration of the fine dust was about three times that in the cotton textile mill. Nicholls (1962) reports a weak smooth muscle contractor activity in the dust collected under the "breakers" in the sisal factory, but too little is known yet of the dose-response relationship of these biologically active natural fibre dusts to interpret the animal bio-assay of the dust quantitatively in man. Our results in the sisal factory do not exclude there being a small effect. The low protein content of the airborne dust is not unexpected in view of the wet retting process which would be expected to remove soluble matter, including much of the smooth muscle contractor substance which is readily soluble. The small amount of coarse dust relative to the medium and fine in this factory, as compared with a typical cotton mill, shows the increase of information obtained by fractionating the airborne dust when comparing mills processing different types of fibre.

The absence of any significant effect in the jute mill confirms the work of Mair et al. (1960). The dust concentrations in the jute mill on the day our studies were made were rather greater than in thesisal factory. The observation of a small rise in I.M.B.C. during the shift in those working in the less dusty parts and a small fall in those working in the dustier parts may indicate a very small effect of the dust which would be in accord with Nicholls' report (1962) of a very weak contractor activity in jute dust.

We believe that these studies demonstrate the usefulness of applying simple tests of ventilatory capacity and of measuring the dust gravimetrically in three sized components to compare the relative health hazards of processing different types of natural fibres. It is also encouraging to find that the ranking of the types of fibres in decreasing order of hazard - cotton $>$ flax $>$ sisal $>$ jute-is similar to that found in the bio-assay of the dusts from these mills and factories.

The investigations were made possible by help very willingly given by many individuals, including the employees who took part in the tests. We are very grateful to them. We wish to acknowledge the great help given by the Managers and Staff of the Factories and Mills, who made facilities available for doing the tests and arranged for power supplies for the dust sampling. We wish to thank the Commissioners of Labour in Kenya and Uganda for their help. We thank Mr. P. D. Oldham for advice in planning and for the statistical analysis. We also wish to thank Mrs. $M$. McDermott for providing a special battery-operated timer for the spirometer, and Mr. A. W. Hyett for construction of the dust samplers.

\section{REFERENCES}

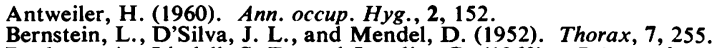
Bouhuys, A., Lindell, S.-E., and Lundin, G. (1960). Thorax, 7, 255. 1, 324.

Davenport, A., and Paton, W. D. M. (1962). Brit. J. industr. Med., $19,19$.

Logan, J. S. (1959). Ulster med. J., 28, 164.

McKerrow, C. B., McDermott, M., and Gilson, J. C. (1960). Lancet, $1,149$. $M e d, \overline{15}, 75$.

Med, 15, 75. Gilson, J. C., and Schilling, R. S. F. (1962). ibid., 19,1.

- - , and Schilling, R. S. F. (1961). J. Amer. med. Ass., 177, 850

Mair, A., Smith, D. H., Wilson, W. A., and Lockhart, W. (1960). Brit. J. industr. Med., 17, 272.

Nicholls, P. J. (1962). ibid., 19, 33.
Paul, R. (1961). Brit. J. Dis. Chest., 55, 30.

Pernis, B., Vigliani, E. C., Cavagna, C., and Finulli, M. (1961). Brit. J. industr. Med., 18, 120.

Roach, S. A. and Schilling, R. S. F. (1960). ibid., 17, 1.

Schilling, R. S. F. (1959). J. occup. Med., 1, 33 .

Smiley, J. A. (1961). Brit. J. industr. Med., $18,1$.

Stott, H. (1958). ibid., 15, 23.

Tuffnell, P. (1960). ibid., 17, 307.

Wright, B. M. (1954), ibid., 11, 284.

- , and McKerrow, C. B. (1959). Brit. med. J., 2, 1041. 